\title{
Sustainable Initiatives in Developing Countries
}

\author{
Antonio René Camargo Aranha de Paula Leite, Jayme de Aranha Machado, \\ and José Benedito Sacomano \\ Paulista University-UNIP, Graduate Program in Production Engineering, \\ Dr. Bacelar St. 1212, São Paulo, Brazil \\ arcapale@unip.br
}

\begin{abstract}
The objective of this work is to present the Production Engineering main concepts that have been orienting the establishment of popular housing programs in Brazil, as a way of reducing its housing deficit and helping boost the social upgrading of the less favored classes. In this presentation are included the building processes presently used, which can guarantee the construction of social houses in less time, following the so called "fast construction" process and the new technologies that make it possible. The civil enterprises concepts on popular housing, most specifically those involving aspects of environmental and sociological sustainability, are also included.
\end{abstract}

Keywords: popular residential housing, "fast construction", building method, environmental comfort, sustainability, robust house.

\section{Introduction}

Brazilian economy, its market free and exporting, reached in 2010, nominal GNP of approximately 2,5, according to IBGE (Brazilian Institute for Geography and Statistics), and this gives Brazil's the seventh place in world's economy, behind only the United States $(14,53)$, China $(5,88)$, Japan $(5,46)$, Germany $(3,29)$, France $(2,56)$ and the United Kingdom (2,25) [6]. The same article suggests that in 2011 Brazil might already have supplanted the United Kingdom's GNP, which would upgrade it to the sixth larger word's economy in $2012[1 ; 2 ; 4]$.

Consistent with the data mentioned above, as the GNP indicates wealth generated by the country, the Brazilian panorama is optimistic as far as the evolution of its economy for the next ten years. Nevertheless, if Brazil's GNP is the world's seventh, quite on the other hand, the per capita GNP is way down to the forty-seventh position, the amount of US\$ 9,390 per inhabitant in 2010, again according to IBGE data, released in 2011.

In order to properly evaluate wealth distribution in Brazil at the present time, two sociological parameters are considered below: the Human Development Index - HDI and the Gini Coefficient. According to the UNDP - United Nations Development Program, data released November 2, 2011, Brazil's HDI for the year mentioned was 0.718, which places the Country at eighty-fourth place in the world, and eleventh in Latin America, behind Chile (0,805), Argentina (0,797), Uruguay $(0,783)$, Cuba 
$(0,776)$, Mexico $(0,770)$, Panama $(0,768)$, Costa Rica $(0,744)$, Venezuela $(0,735)$, Peru $(0,725)$ and Equator $(0,720)$.

The other parameter that describes social inequalities in Brazil is the Gini Coefficient, which, at its last release in 2009, referring to year 2008, attributed to Brazil value 0.544. It should be remembered that this coefficient varies from zero (all population has the same income) to one (only one person has the country's total income). Therefore, it becomes visible that in Brazil there is high income concentration. For comparison, we show value and reference year for a few countries: Mexico 0.479 (2006), United States 0.450 (2007), China 0.470 (2007), France 0.327 (2008), Portugal 0.385 (2008) and Norway 0.250 (2008). Of course these countries have better wealth distribution than Brazil. It is therefore inferable that Brazil, although a powerful generator of wealth, distributes poorly its wealth among its society $[3 ; 5]$.

The aim of this paper is to present the way Production Engineering perceives Brazil's housing scenario. It will focus specifically the popular housing construction programs and the technological advances of the so called "fast construction", which has experienced consistent development. This has led to an optimistic expectation of diminishing the Brazilian housing deficit for low income families.

\section{$2 \quad$ Methodology}

The research was based on technical and economic documents related to the onefamily residence projects implanted by the company MEGASCI -Sistema Construtivo Industrializado, researched by the authors. MEGASCI (www.megasci.com.br), with headquarters in São Paulo, has gained recognition for technologic innovations brought up into the construction of housing projects in concrete. Records on calculations, drawings, building methods and budgets were examined during the last four years and thus a thorough view of these technologic innovations was made possible. They are characteristic of the "fast construction", as it is understood today in Brazil.

\section{$3 \quad$ Results and Discussion}

\section{Brazil's Present Day Housing Scenario}

In several opinion polls about Brazilians' most desired goods [see http://www. correiocidadania.co.br/content/view/3560/91], for all levels of income, home ownership is number one, especially for wage earning workers who have no other way to buy a house, other than (federal, state or municipal) government sponsored programs.

The 2010 IBGE's Census showed that 11.4 million Brazilian (6\% of population) live in below normal level conglomerates, like favelas (slums), palafitas (houses on stilts) and mocambos (miserable dwellings, formerly, refuges of runaway slaves) and other kinds of social assemblages, all characterized by the poverty of its people. It should be noted that in São Paulo's metropolitan area there are 2.1 million dwellers in 
such conditions. The state capital which its metropolitan area shows the worst rate of slum dwellers is Belem, with $51 \%$ of its inhabitants living in slums.

\section{Housing Programs and Social Upgrading}

As far as the Brazilian Federal Government is concerned, several housing programs were offered to the poorest social levels, families earning 3 to 5 minimum wages per month (US\$ 950.00/month) in order to diminish the country's housing deficit. Among the various federal housing programs, the BNH - National Bank of Housing, formed during the military regime in 1964 and extinguished in 1986, and the Minha Casa Minha Vida (My home, my life), presently in progress, and with promising perspectives. While the National Housing Plan, conducted by BNH focused only in the construction of popular dwellings, Minha Casa, Minha Vida was devised to promote social upgrading of families most in need, equipping housing nuclei with sanitary infrastructure (water and sewage), transportation, social addenda (schools, daycare centers for babies and young children, health centers, recreation clubs, etc.), so that when occupying a new dwelling, a family is automatically inserted in the area's social context.

It should be emphasized that Minha Casa, Minha Vida is offered through agreements and partnerships of the federal government with state and municipal governments and they act jointly in the installation of these housing nuclei: usually the federal government is responsible for management and financial resources, to the state is left investments on urban infrastructure and the municipality contributes with the area and future means of collective transportation.

\section{New Technologies and "Fast Construction" in Brazil}

The main technological advancements that allowed Brazil, from year 2000 on, to install in a fast and efficient manner popular housing nuclei of good quality were:

1. Metallic modules with the house installations inside: potable water, sewage, electricity; it allows the finishing of walls already with these modules inside.

2. Ad mixtures to control concrete density in order to obtain different degrees of air entrained concrete, which allow concrete walls and roof to keep thermal comfort inside the houses.

3 Ad mixtures to control concrete fluidity, for easier use, increased construction speed e better structure quality.

Apart from these technological advances at civil construction, it should be mentioned that both government and private companies have intensified training of the work force preparing professionals to work with industrialized building systems.

\section{A Proposal for 'Robust House' in the Context of Popular Housing}

Consequently, it is proposed as a promising alternative for the residential industrial construction of dwellings for low income population, the 'robust house', an idea based on the following social and economic building concepts: 
1 Concrete prepared of Portland cement as the sole building material for the structure, which comprises the foundation over a radier plate, walls of concrete with mechanical modules already installed inside, and the concrete roof, with special added products to provide thermal comfort inside.

2 One store residence, area of $50 \mathrm{~m}^{2}$, with multi-use living room, two bedrooms, one bathroom, kitchen and porch.

3 Sale price from 20 to 25 thousand US dollars.

4 Plots of land from 70 to $90 \mathrm{~m}^{2}$., backyard with barbecue installation, an important Brazilian social custom, which often includes the presence of relatives and neighbors.

5 Fences separating the residences to protect the family's privacy, another important item in Brazilian culture.

6 Robust houses are built inside a housing nucleus with social facilities: school, daycare center for babies and young children, recreation club, medical center, etc.

7 Infrastructure with potable water supply, sewage system, electricity, flammable gas for cooking, paved streets, etc.

8 Reutilization of all rubble from construction, at all phases.

9 Housing projects with solar energy absorber devices, reutilization of water in dwellings, retention and utilization of rain water and other items necessary to environmental sustainability.

It's reasonable to believe that, provided the above items are fulfilled, families living in a popular housing nucleus like this will be effectively upgraded and inserted into the Brazilian society.

The final deduction, after careful analysis of the technical documentation, and visits to the Housing Nuclei built by the above mentioned company, is that the "fast construction" process has been consolidated as a powerful social and technical instrument for the implantation of dwellings specially made for low income families. At the same time, this complete set of technologic innovations of the building methods in use today may and will be progressively amplified, adopting future ideas and procedures that will maintain the same quality of the residences, but at a lower cost and smaller construction time.

\section{$4 \quad$ Final Remarks}

This analysis of the implanted projects led us to reach the following conclusions:

1. The Federal Government sponsored program so-called "Minha Casa, Minha Vida" - My House, My Life - has been showing remarkable results, mainly because in it the three levels of government (Federal, State and Municipality) are involved and aiming at the same objective, that is, to reduce the dwellings deficit in the country by building houses integrated to Housing Nuclei, which allow for effective social integration of low income families.

2. The technologic innovations herewith described refer to concrete as the building material that made possible a new construction process called Fast Construction, 
in which the construction speed is an important factor to reduce the dwellings deficit in Brazil.

\section{References}

1. Montoya, P.J.: Hormigon Armado. Editora Gustavo Gili S.A., Barcelona (2010)

2. Miguel, P.A.C.(Organizador): Metodologia de Pesquisa em Engenharia e Gestão de Operações. Eliever Editora Ltda., Rio de Janeiro (2012)

3. Sacomano, S.B., et al.: Administração de Produção na Construção Civil. Editora Arte e Ciência, São Paulo (2008)

4. Santoro, P., Bonduki, N.G.: Expansão Urbana em Questão: Instrumentos para Organizar o Crescimento das Cidades. Instituto Polis, São Paulo (2012)

5. Tigre, P.B.: Gestão da Inovação. Elsevier, Rio de Janeiro (2006)

6. Veja-Editorial, p. 76 (January 4, 2012) 